\title{
UNDERSTANDING THE EMIGRATION PROPENSITY OF ROMANIAN TEACHERS: DOES ETHNICITY PLAY A ROLE?
}

\author{
Angel-Alex HĂISAN - Zizi GOSCHIN - Mihai AVORNICULUI
}

(Received: 25 March 2016; revision received: 11 July 2016; accepted: 22 July 2016)

\begin{abstract}
Mass migration was, is, and will always be an important topic of discussion regardless of whether it is economically, socially, or politically motivated. This is certainly a matter of great concern for Romania, currently Europe's largest sender of migrants to Western Europe. Considering that the educational system should be of the uttermost priority, we addressed the issue of emigration propensity among Romanian teachers making use of data from our own nationwide survey. Bivariate logistic models were employed to identify the main factors behind the emigration decisions of pre-university teachers. Aiming to enrich the narrow economic perspective, we adopted a novelty approach by focusing on an overlooked determinant in emigration research studies, namely ethnicity in relation to nationality. Among Romania's minorities, Hungarians are the most important ethnic group, accounting for $6.1 \%$ of the population, hence we explored their migration behaviour compared to Romanian ethnics. The results from the logistic regression models indicate significant differences regarding the factors that trigger the intention to initiate the emigration process for our subjects, based on their ethnicity. We found that teachers of Hungarian ethnicity display $50.6 \%$ less propensity to emigrate compared to the ones of Romanian ethnicity and we were able to shape distinct emigration profiles for the two groups.
\end{abstract}

Keywords: emigration, teachers, ethnicity, logistic model, Romania

JEL classification indices: I21, J24

Zizi Goschin, corresponding author. Professor at the Bucharest University of Economic Studies, Department of Statistics and Econometrics, Bucharest, Romania. E-mail: zizi.goschin@csie.ase.ro

Angel-Alex Hăisan, Lecturer at "1 December 1918” University, Faculty of Law and Social Sciences, Alba Iulia, Romania. E-mail: haisan-angel@hotmail.com

Mihai Avornicului, Lecturer at the Babes-Bolyai University, Faculty of Economics and Business Administration, Department of Economics and Business Administration in Hungarian Language, Cluj-Napoca, Romania. E-mail: mavornicului@yahoo.com 


\section{INTRODUCTION}

Why do humans migrate? If we return to the very basics of our nature, the animal world, we will immediately find the raw answer: if a living creature considers the environment in which it lives not to be propitious for life because basic requirements regarding security and physiological needs can no longer be fulfilled, they abandon it after first trying to adapt and search for a better one. While things in the animal world tend to be relatively simple because only basic principles govern it, in humans' world, when reason exerts its duties, it becomes rather complicated. Human migration was, is, and will always be an important topic of discussion and regardless of the motivations involved, it stood at the foundation of many modern nations (Leiden University 2016).

Massive Romanian emigration is currently a major concern, Romania being the largest sending country to the western European Union countries (Eurostat 2016). It is particularly worrying that a culture of emigration is emerging in case of the rural population, which is predominant in Romania (Horváth 2008), as is the fact that most of the emigrants are young people of up to 35 years old (Hăisan 2013; Goschin - Roman 2014). Moreover, in addition to the wave of low-skilled workers, there has been a massive brain drain in past years, affecting mainly the health and IT sector (Goschin - Roman 2014). Since human capital is acknowledged as an asset of high importance for the development of any country (International Labour Organization 2002), the emigration of highly skilled workers becomes a problem of the uttermost importance that requires immediate intervention based on a proper understanding of the social and economic conditions that induce it.

Although the brain drain in Romania is mainly associated with the health and IT sectors, in reality the emigration flows currently include highly qualified personnel from all areas of life, especially from those that ensure a society's proper functioning. Considering that the general direction of humanity is globalisation, it is possible that the demand for highly qualified personnel will increase in the near future in areas that are not so sought after today such as education, justice, economy, etc. For example, in education, although national systems still differ at present, they all have a proclivity towards adapting a common means of communication, the English language. In the field of education, in addition to the short-term "go-learn-return" programs which encourage teachers' international mobility in order to gain expertise and implement it upon returning into the sending country, there are also long-term programs of one to three years such as the Teacher Program in the US, which recruits teachers from all over the world in order to fill a gap in their system. Within the British Commonwealth, experts are already talking about a developed brain drain phenomenon, which could create 
a precedent and affect other countries in the near future (Department for International Development 2006; UNESCO 2011).

In our previous studies, we found that the main reason for the emigration of Romanian teachers is low income, but discontent regarding under-funding, systematic decline of student population, and insufficient investment in schools' infrastructure are also important (Hăisan 2013). Building on these results, we are now aiming to enrich the narrow economic perspective through the inclusion of additional factors that might influence emigration propensity, focusing on ethnicity. Our approach is justified by the dissimilarities observed among potential migrants in relation to their ethnicity. Among minorities, Hungarians are the most important ethnic group in Romania, representing $6.1 \%$ of the population according to the 2011 census, hence we intend to explore their emigration intentions compared to those of Romanians. To our knowledge this line of research represents a novelty in migration studies.

The general approach of this topic is a preventive one rather than problem solving. The paper tries to raise awareness of a subject that exists, but has not been particularly visible so far.

The remainder of this paper proceeds as follows. The next section briefly reviews the relevant literature. Section 3 explains the research methodology, alongside the variables employed in the analysis and the data source, while Section 4 discusses the results obtained from estimating the regression models focusing on the differences between the emigration profiles of the two studied groups. Finally, Section 5 concludes and outlines possible directions for future research.

\section{LITERATURE REVIEW}

The educational system should be of the uttermost priority to any country, especially for developing ones, as it is considered to be one of the most powerful weapons and a propellant for a better future of nations.

A high emigration wave of teachers was registered in Romania immediately after the fall of communism (Timmerman et al. 2015). A report on trends in international migration compiled by the OECD in 2002 revealed significant changes in teachers' emigration from Romania compared to 2000 , i.e. an increase by $24.6 \%$ (OECD 2003). A recent report of the OECD also warned about the emigration of highly skilled personnel from Romania, among them also teachers (OECD 2015).

Successful cases of Romanian emigrant teachers that continued to practice the same profession were reported mainly for English teachers who headed towards the UK, the US, the UAE and other English-speaking countries, or for 
those who held courses on language, culture, and Romanian civilisation in Italy, Spain, Belgium, Ireland, and Portugal (Romanian Language institute 2016), but there are also many less fortunate cases of teachers who needed to readjust to other fields of work following emigration. The fact that in all our previous studies targeting teachers we found high percentages of persons who expressed emigration intentions reflects the smouldering nature of this matter (Hăisan 2013). In consequence, there is a need for a more thorough exploration of the emigration drivers because a better understanding of the phenomenon could help decisionmakers to prevent high emigration flows from this sector. Teachers' emigration might worsen the already registered deficit of pre-university teaching personnel, particularly in rural areas (Institute for Education Sciences 2015; UNESCO Institute for Statistics 2014), with specialists estimating that Romania will need to recruit 41.3 thousand new teachers by the end of 2030 in order to ensure access to education for every child (UNESCO 2016).

One of the reasons that teachers' migration was not a mainstream problem so far is the fact that in order to emigrate as a teacher to another country, you need, above all, to master the language of that country. The average age of Romanian teachers is 42 years, which means that a large percentage is over the 50 years threshold (OECD 2013). Moreover, as age increases, the will to emigrate decreases. Additionally this group does not have a high proficiency in English because its members received their education during communism, a doctrine that did not favour it. In the future, once younger and better-skilled persons will enter the ranks of teaching staff, this language barrier should fall and teacher emigration might emerge as an acute problem. Also, because of globalisation and the rapid propagation of information via the internet, increasingly more common cultural experiences are created, which can facilitate an easier adaptation.

Since there are very few data on Romanian teachers' emigration, we need to learn from other countries experiences. Teachers' migration is a relatively new phenomenon, but it has experienced a constant growth in the last two decades. A plethora of studies have emerged over the last years, covering a large array of directions from general ones (Appleton et al. 2006; Abramova 2015; Iredale et al. 2012) to more particular ones (Nakahara - Black 2007; Ramirez et al. 2015). Teachers' emigration is also becoming a concern for important international organisations in the field, which have started to address the issue and publish their own reports (American Federation of Teachers 2009; UNESCO 2011; OECD 2015). A brilliant comprehensive review of the empirical sources available on teachers' emigration is available in the Educational Research Review (Bense 2015).

The topic of teachers' migration can range from success stories and exceptional personal development to maladjustments and exploitation (Caravatti et al. 2014). Most studies in the literature refer to the movement of educational per- 
sonnel within the British Commonwealth territory presumably because they already have a common denominator - the English language - and a shared cultural background. The teaching profession is underpaid in most of worlds' countries regardless of their geographical location (Mastekaasa 2011), and thus the actual financial gain of this job is exerted only if a person moves to a more developed country. The international context is favourable in this aspect because many developed English-speaking countries such as the UK, the US, Canada, Australia, etc. are currently experiencing shortages in teaching staff due to their inability to enrol young people into the system (South African Council for Educators 2011). Thus, driven mainly by financial reasons, but also by socio-cultural ones, teachers from large underdeveloped countries such as India and South Africa, but also from small ones like Jamaica and the Cayman Islands migrated to the UK and the US (Sharma 2012). While the loss was bearable for the larger countries, it was devastating for the small ones, and as a consequence the Commonwealth Teacher Recruitment Protocol was introduced (Education International 2016).

The impact of teachers' migration for the sending countries, mostly underdeveloped ones, represents a "double loss" (Sharma 2012), firstly in human capital and secondly in growth prospects (Bense 2015). Based on a push-pull factor (Brubaker 1998), it seems that a new market developed, where demand and supply created two types of countries, auspicious for emigration or for immigration (Fitzgerald 2005). Furthermore, receiving countries also differentiate based on the specialisations needed, thus diversifying the emigration phenomenon (Cooper - Alvarado 2006). For example, Australia lost large numbers of Australian trained teachers to countries like the UK, but compensated for it by receiving teachers from New Zeeland, Ireland, Germany, and other countries (Collins Reid 2012). If Australia can be, overall, a positive example of teacher immigration experience, there are also less successful stories. Many teachers from Asian countries paid large sums of money to recruiting agencies hoping for a better life in the US, but once they arrived there, they were forced to face reality and accept jobs in underdeveloped problematic communities (American Federation of Teachers 2009).

Most of the studies that tried to understand the motivations behind teachers' emigration point out that the quality of the educational system of the sending country, along with economic and professional opportunities from the receiving country, are the major determinants (Appleton et al. 2006; Manik 2014). Job satisfaction is a highly important factor in a persons' life and it seems that it can also vary based on cultural heritage. Researches in this area report that in South-Eastern European countries, cultural heritage has a more pronounced effect on job satisfaction that in the Central and Eastern European (CEE) countries (Mojsoska-Blazevski et al. 2015). 
The research literature abounds in studies on migration in relation to ethnicity both within national borders (Finney - Simpson 2008) and without (Norredam et al. 2011; Bhopal 2014), but none of them has yet offered a comparison of emigration of persons born and raised in the same citizenship/nationality, but having different declared ethnicities. On a national level, several studies have approached Romanians' emigration; however there is hardly any data on the subject of emigration of Romanian ethnic minorities. The few available studies focus on the emigration of the Saxons (Koranyi - Wittlinger 2011), the Szekelys (Godri 2004; Kocsis 2007) or the Croats (Anghel 2012).

\section{MODEL, VARIABLES, AND DATA}

This paper explores the emigration propensity of Romanian teachers, based on their individual attributes and opinions, by using probabilistic models, namely logistic models, which are a popular choice in analysing migration decisions (Aryal 2005; Islam et al. 2013; Cai et al. 2014).

We employ bivariate logistic models to identify the factors behind the emigration decision of the teachers having different ethnic backgrounds. The regression model allows predicting the logit, i.e. the natural $\log$ of the odds that a certain event takes place:

$$
\ln (O D D S)=\ln \left(\frac{\hat{p}}{1-\hat{p}}\right)=\hat{\beta}_{0}+\hat{\beta}_{1} X_{1}+\hat{\beta}_{2} X_{2}+\ldots+\hat{\beta}_{k} X_{k}
$$

The dependent variable, $Y$, is a dummy, equal to 1 if the respondents intend to emigrate and 0 otherwise, while $\hat{p}$ is the predicted probability of emigrating from Romania, $1-\hat{p}$ is the predicted probability of the opposite decision, and $X_{i}$ are explanatory variables.

We also used a Chow type test for structural stability, in a form appropriate for the logistic regression model, to determine whether separate regressions for the two groups envisaged in our research (teachers of Romanian and Hungarian ethnicity) are more efficient compared to a single model for the entire database. The statistic for this test was as follows (Allison 1999; DeMaris 2004):

$$
\chi^{2}=-2 \ln \mathrm{L}_{\mathrm{all}}-\left[\left(-2 \ln \mathrm{L}_{1}\right)+\left(-2 \ln \mathrm{L}_{2}\right)\right]
$$

where $\ln L_{a l}$ is the $\log$-likelihood for the entire sample and $\ln L_{1}$ and $\ln L_{l}$ represent the $\log$-likelihood for group 1 and group 2, respectively. The statistic of the test has a $\chi^{2}$ distribution with the degrees of freedom equal to the difference be- 
tween the sum of parameters in the separate models and the number of parameters in the combined model.

The explanatory variables described in Table 1 are factors that might influence the decision to emigrate. They represent individual characteristics of respondents, family attributes, information on employment and earnings, as well as their opinions on a variety of socio-economic topics that capture their subjective wellbeing and quality of life.

Table 1. The variables

\begin{tabular}{|c|c|c|}
\hline Variable name & Description & Measurement \\
\hline \multicolumn{3}{|c|}{ Personal characteristics } \\
\hline Age & Age of the respondents, in years. & scale \\
\hline Gender & Gender of the respondents, 1 for female and 0 for male. & binary \\
\hline Married & $\begin{array}{l}\text { Marital status of the respondents, } 1 \text { if married and } 0 \\
\text { otherwise. }\end{array}$ & binary \\
\hline Child & Number of children of the respondents. & scale \\
\hline \multicolumn{3}{|c|}{ Family } \\
\hline Family_importance & $\begin{array}{l}\text { Respondents' evaluation of the role of family in their } \\
\text { life: } 1 \text { if family is considered very important and } 0 \text { if it } \\
\text { is important (nobody valued family less than impor- } \\
\text { tant): }\end{array}$ & binary \\
\hline Keeping_in_touch & $\begin{array}{l}\text { Respondent's contact with close relatives: } 1 \text { if the } \\
\text { respondent is currently keeping in touch with family } \\
\text { and } 0 \text { otherwise. }\end{array}$ & binary \\
\hline \multicolumn{3}{|c|}{ Subjective wellbeing } \\
\hline Satisfaction & $\begin{array}{l}\text { Respondents' evaluation of their general life } \\
\text { satisfaction: ranging on a scale from } 1 \text { to } 10 .\end{array}$ & ordinal \\
\hline Happiness & $\begin{array}{l}\text { Respondents' evaluation of their state of happiness: } \\
1 \text { if the respondent feels happy and } 0 \text { otherwise. }\end{array}$ & binary \\
\hline Romania_direction & $\begin{array}{l}\text { Respondents' evaluation of Romanian society } \\
\text { trajectory: } 1 \text { if the respondent believes that Romania is } \\
\text { going in the right direction and } 0 \text { otherwise. }\end{array}$ & binary \\
\hline Optimism_future & $\begin{array}{l}\text { Respondents' evaluation of their state of optimism } \\
\text { regarding the future: } 1 \text { if the respondent is optimistic } \\
\text { about his/her future and } 0 \text { otherwise. }\end{array}$ & binary \\
\hline \multicolumn{3}{|c|}{ Health } \\
\hline Health & $\begin{array}{l}\text { Respondent's evaluation of personal health, on a scale } \\
\text { from } 1 \text { to } 5 \text {. }\end{array}$ & ordinal \\
\hline Healthcare & $\begin{array}{l}\text { Respondent's evaluation of the Romanian healthcare } \\
\text { system: } 0 \text { if inadequate (reference group), } 1 \text { if good, } 2 \\
\text { if very good. }\end{array}$ & ordinal \\
\hline
\end{tabular}


Table 1. continued

\begin{tabular}{|c|c|c|}
\hline Variable name & Description & Measurement \\
\hline \multicolumn{3}{|c|}{ Income } \\
\hline Pay_bill & $\begin{array}{l}\text { Respondents' evaluation of their capacity to cope with } \\
\text { monthly expenditures: Insufficient income is captured } \\
\text { through a binary variable equal to } 1 \text { if the respondent } \\
\text { experienced difficulties in paying the bills during the } \\
\text { last } 12 \text { months and } 0 \text { otherwise. }\end{array}$ & binary \\
\hline Earnings & Average monthly income of the respondents. & scale \\
\hline \multicolumn{3}{|c|}{ Job } \\
\hline Second_job & $\begin{array}{l}\text { Existence of a second job: } 1 \text { if the respondent has a sec- } \\
\text { ond job and } 0 \text { otherwise (all respondents are employed). }\end{array}$ & binary \\
\hline New_job & $\begin{array}{l}\text { Respondents' evaluation of their employability: } \\
1 \text { if the respondents consider that they could easily find } \\
\text { a similar or better job if the current one is lost and } \\
0 \text { otherwise. }\end{array}$ & binary \\
\hline \multicolumn{3}{|c|}{ Education } \\
\hline Education_satisf & $\begin{array}{l}\text { Respondents' evaluation of their satisfaction regarding } \\
\text { personal education: on a scale from } 1 \text { to } 10 .\end{array}$ & ordinal \\
\hline New_courses & $\begin{array}{l}\text { Respondents' availability towards improving their } \\
\text { education: } 1 \text { for the respondents who aim to improve } \\
\text { their education by attending training courses or gaining } \\
\text { a new bachelor, master, doctoral, or postdoctoral degree } \\
\text { and } 0 \text { otherwise. }\end{array}$ & binary \\
\hline \multicolumn{3}{|c|}{ Housing } \\
\hline House_satisf & $\begin{array}{l}\text { Respondents' evaluation of their lodging: on a scale } \\
\text { from } 1 \text { to } 10 .\end{array}$ & ordinal \\
\hline \multicolumn{3}{|c|}{ Corruption } \\
\hline Bribe & $\begin{array}{l}\text { Respondent's rights infringement: } 1 \text { if the respondent } \\
\text { had to offer a bribe during the last } 12 \text { months and } 0 \\
\text { otherwise. }\end{array}$ & binary \\
\hline \multicolumn{3}{|c|}{ Environment } \\
\hline Safety & $\begin{array}{l}\text { Respondents' perception of their safety: } 1 \text { if the } \\
\text { respondent experienced threats during the last } \\
12 \text { months and } 0 \text { otherwise. } \\
\end{array}$ & binary \\
\hline Environment_quality & $\begin{array}{l}\text { Respondent's evaluation regarding the quality of living } \\
\text { environment: } 1 \text { if the respondent is disturbed by the dirt } \\
\text { and garbage in public spaces and } 0 \text { otherwise. }\end{array}$ & binary \\
\hline Public_transport & $\begin{array}{l}\text { Respondent's evaluation regarding the quality of public } \\
\text { transport: } 1 \text { if the respondent is satisfied by the quality } \\
\text { of public transport and } 0 \text { otherwise. }\end{array}$ & binary \\
\hline
\end{tabular}

The necessary data for estimating the models came from a wider research, one that aimed to identify the quality of life of the Romanian pre-university teachers and how it varies within national borders, between the NUTS-2 regions. Data collection took place between January and March 2015 and utilised a self-designed 
questionnaire based on the one used by the European Quality of Life Surveys (EQLS, Eurofound 2016). We have designed the questionnaire as a simpler, more accessible version of the one used by EQLS envisaging 12 domains that define the quality of ones' life: health, job, income, education, family, social involvement, house, environment, transport infrastructure, personal safety, free time, and life satisfaction. The questionnaire featured a suite of 72 questions, targeting both personal and family profiles of the respondents, as well as their opinions on a variety of factors related to their well-being, and generated a final database of 395 unique valid entries, each one having no less than 155 variables. Beside the 12 questions about personal data, 5 questions have been attributed to each domain of quality of life. These were of a closed type, the most used being dichotomous and five variants ones. Likert scaling was used as well. The questionnaire was uploaded on Google Forms platform and distributed within databases from previous researches, official national educational portals, and specifically targeted educational institutions in order to cover national territory and active communities of teachers on Facebook. We achieved a good territorial coverage and all NUTS-2 regions were well represented in the final database. Because our database was constructed for broader research purposes, not only migration, some questions directly related to the subject such as expected job after migration or whether their qualification is transferable were unfortunately omitted from the questionnaire. Nevertheless, we believe that the respondents were probably unlikely to have provided valid answers to such questions, as most of them have little information on job opportunities in their targeted destinations.

All the variables relevant for the emigration intention of the respondents in our database have been tested and Table 1 displays only those that were statistically significant at the $10 \%$ threshold. These variables will be included as regressors in the models to be further estimated.

\section{RESULTS AND DISCUSSION}

Once the information gathered from the respondents was centralised, we could review the data in a manner that permitted us to grasp the most significant irregularities. The most striking one was that although all our respondents were of the same nationality - Romanian - their intention to emigrate as well as other personal defining characteristics differed significantly according to their declared ethnicity. Therefore, beside running tests on the entire database, we also decided to split it into two datasets based on the afore-mentioned variable in order to be able to conduct further, more precise analyses. The newly obtained databases were similar regarding the number of respondents, so they were comparable. 
Based on a general towards specific principle, we assumed that profiling our subjects might help us in the following research steps. Therefore, we proceeded by firstly sketching the general characteristics of the potential Romanian nationality emigrant teacher and secondly by pointing out some first view differences based on their ethnicity.

We found that the average potential emigrant teacher of Romanian nationality is relatively young (37.6 years), married ( $84 \%)$, has one child, highly values his/ her family, and is in a good state of health. Although their subjective life satisfaction and happiness are on average relatively high (6.34 and 6.57, respectively, on a scale from 1 to 10 ), they are not optimistic about their future (70\%) and believe that Romania is not going in the right direction. They are relatively satisfied with their education, but are willing to further improve it by taking various training courses or attending new bachelor, master, doctoral, or postdoctoral courses (73\%). Their mean monthly income is RON 1225, well below the average wage in Romania, which explains why about $42 \%$ of the potential emigrants encountered difficulties in paying their bills during the last 12 months and $39 \%$ have a second job. Among the potential emigrant teachers, $30 \%$ experienced threats and $53 \%$ offered a bribe to someone during the last 12 months.

The teachers that declared themselves of Romanian ethnicity are more likely to emigrate, $41.3 \%$, while only $16.3 \%$ of those who stated that they are of Hungarian ethnicity would like to do so. Reviewing the research literature on emigration of Romanian minorities, an interesting aspect arises from comparing the Saxon and Szekely emigrants, namely that the Romanian Saxons were recognised as Germans upon entry to Germany (Brubaker 1998), while the Romanian Szekelys were not recognised as Hungarians (Fox 2007). This could explain why only 4\% of the Romanian teachers of self-declared Hungarian ethnicity who expressed an intention to emigrate would emigrate to Hungary.

Teachers of Romanian and Hungarian ethnicity differ in other attributes as well. Although those who have declared themselves of Romanian ethnicity have higher incomes, they are less successful in meeting their current needs and have encountered difficulties in paying their bills more frequently ( $49 \%$ of the teachers of Romanian ethnicity, compared to $17 \%$ of the teachers of Hungarian ethnicity). The frequency of a second job is higher among persons of Romanian ethnicity ( $42 \%$, compared to $26 \%$ ), which explains their higher revenues. Their optimism also contrasts sharply: only $18 \%$ of the teachers of Romanian ethnicity declared that they felt happy and optimistic in the last two weeks, against $61 \%$ of the teachers of Hungarian ethnicity. Also, $24 \%$ of the persons of Romanian ethnicity declared themselves to be optimistic about their future, compared to $57 \%$ of the persons of Hungarian ethnicity. Such dissimilarities transpose into different options regarding emigration and are therefore relevant for our research. 
Chi-square tests were used to assess the relationship between the emigration decision and the other variables. We found that age, family, personal health and quality of the healthcare system, insufficient income, optimism about the future, the level of satisfaction regarding education and housing, threats, environment, and quality of public transport were statistically significant for the emigration intention in the case of the teachers of Romanian ethnicity, while in the case of the teachers of Hungarian ethnicity, the significant variables were age, intention to improve education, family links, corruption, happiness, perception that Romania is going in the right direction, and public transport quality. All other variables in our databases hold a low relevance for the emigration decision, and they have therefore not been included in the final regression models' specifications.

After these brief introductory descriptive statistics, we proceeded to some more detailed analysis, aimed at demonstrating if there is actually a difference regarding the factors which trigger the intention to initiate the emigration process of our subjects, based on their ethnicity.

We ran binary logistic models for the whole dataset and separately for each subgroup: teachers of Romanian and Hungarian ethnicity. In order to validate them, the standard statistical tests were applied and all three models proved to be significant (see Tables 2, 3 and 4). The significance of the Hosmer-Lemeshow test exceeds the 0.05 threshold, proving that the models fit the data very well. The models explain in good proportion the emigration intentions of the teachers in the common database (Nagelkerke $\mathrm{R}^{2}=0.341$, Cox-Snell $\mathrm{R}^{2}=0.245$ ) as well as for Romanians (Nagelkerke $\mathrm{R}^{2}=0.321$, Cox- Snell $\mathrm{R}^{2}=0.239$ ) and for the Hungarians (Nagelkerke $\mathrm{R}^{2}=0.608$, Cox-Snell $\mathrm{R}^{2}=0.361$ ) and predict correctly $73.3 \%, 70.7 \%$, and $90.4 \%$ of the cases, respectively.

In order to validate our option for separate models (Romanians $v s$. Hungarians), we performed a test analogous to Chow test, appropriate for logistic regression (DeMaris 2004), to assess the difference in fit between the global model and the separate models for our two groups. The $\chi^{2}$-statistic of this test is 48.909 , well above the critical value of 2.733 (for a threshold of 0.05 ), therefore we can confidently reject the null hypothesis that there is no difference between the models.

First, we ran a logistic regression on the dependent variable "intention to emigrate" using the whole database and the results (Table 2) were largely in accordance with our expectations, but also provided a few surprises. One unexpected result was that none of the income variables that were tested seemed to have a significant influence on our respondents' propensity to emigrate, although the prospect of higher earnings is considered to underlie many emigration decisions (both international and within the same country) (Heid - Larch 2012; Vojtovich 2013). Conflicting results have also been reported by other studies (de Haan Yaqub 2009) and we consider that our finding could be explained by the income 
homogeneity of the database: since all of our respondents are well educated and active in the same sector, it is natural to have relatively similar earnings.

As indicated by the descriptive statistics, ethnicity is relevant for the emigration intentions of the pre-university teachers: persons of Hungarian ethnicity display $50.6 \%$ less propensity to emigrate compared to the ones of Romanian ethnicity.

In line with many studies concerning emigration determinants, our results indicate age as an important factor of influence: young people are more likely to emigrate as they are in good health, usually have no children to take care of (or have less children), are more energetic, adventurous, and less risk-adverse compared to older people (Hăisan 2013; Peri 2013; Global Migration Group 2014; International Labour Organization 2002). We estimated a negative and highly significant coefficient on the age variable. The odds ratio $(\operatorname{Exp}(B))$ of 0.953 indicates that the emigration likelihood drops by $4.7 \%$ for each additional year of age (Table 2).

Family is important for all our respondents, an aspect that should be of no surprise, given the very high share of women in the database. Women tend to be more adverse to family separation, especially when children are involved. Since none of the respondents valued family less than important, the variable "family importance" was recorded into a binary one: 1 if family is considered very impor-

Table 2. Results from the logistic regression on emigration intention of pre-university teachers

\begin{tabular}{l|r|r|r|r|r}
\hline Variables & \multicolumn{1}{|c|}{ B } & S.E. & Wald & Sig. & Exp(B) \\
\hline Age (years) & -0.048 & 0.017 & 80.201 & 0.004 & 0.953 \\
\hline Respondent is Hungarian & -0.704 & 0.333 & 40.484 & 0.034 & 0.494 \\
\hline Family is very important & -10.216 & 0.489 & 60.194 & 0.013 & 0.296 \\
\hline Has a second job & 0.579 & 0.296 & 30.823 & 0.050 & 10.783 \\
\hline Job is safe & -0.219 & 0.126 & 30.016 & 0.082 & 0.803 \\
\hline Aims to improve education & 0.608 & 0.311 & 30.829 & 0.050 & 10.837 \\
\hline Respondent is satisfied & -0.256 & 0.084 & 90.228 & 0.002 & 0.774 \\
\hline $\begin{array}{l}\text { Romania is going in the right } \\
\text { direction }\end{array}$ & -0.638 & 0.179 & 120.665 & 0.000 & 0.528 \\
\hline There is corruption & 0.487 & 0.287 & 20.875 & 0.090 & 10.628 \\
\hline There are threats & 0.849 & 0.335 & 60.415 & 0.011 & 20.338 \\
\hline Constant & 30.958 & 10.084 & 130.339 & 0.000 & 520.342 \\
\hline Statistics & 330 & & & \\
\hline Number of observations & $14.061(0.080)$ & & \\
\hline $\begin{array}{l}\text { Hosmer and Lemeshow Test } \\
\text { (sig.) }\end{array}$ & 0.341 \\
\hline Nagelkerke R Square & 0.245 & & & \\
\hline Cox-Snell R Square & & & & \\
\hline
\end{tabular}


tant and 0 if important (the reference category). The coefficient estimated for this binary variable is negative and statistically significant, meaning that strong family ties discourage emigration. The corresponding odds ratio of 0.296 indicates that the risk of international emigration is lower by $70.4 \%$ for the respondents who rate family as being very important in their life, compared to the reference group.

The emigration propensity is 11 times higher for respondents who have a second job. Employment in a second job indicates that the principal job does not provide satisfactory income for the individuals' well-being, which is a potential trigger for emigration. A second job is also an indicative for the hard-working, ambitious, and determined character of our respondents, which should help them to accommodate easier to the challenges of the competitive labour market abroad, while the additional work experience from a side job might offer higher chances of employment and professional success. Such assets bring self-confidence and risk acceptance, therefore might explain the higher emigration intention.

Respondents who aim to improve or diversify their education and are willing to attend training courses or study for a bachelor, master, doctoral, or postdoctoral degree, display an emigration intention 11 times higher compared to those who are satisfied with their current education. Education improvement is a major investment for the future, as skilled and well-educated persons are more likely to find good jobs. Respondents who target better education are more confident and optimistic about their career prospects, hence more likely to accept the risks and challenges of getting appropriate employment abroad.

The subjective perception of personal well-being finds itself in an inverse relationship with the propensity to emigrate. Persons who are content with their current situation exhibit a $22.6 \%$ less emigration intention in comparison with the dissatisfied ones. This suggests that unhappy persons hope to improve their life by emigrating.

The subjective perception that Romania is going into the right direction halves the emigration propensity of the teachers in our survey (odds ratio of 0.528 ). This result indicates that the improvement of social, political, and economic conditions in Romania is a key factor for reducing the out-migration flows (Goschin - Roman 2014).

Respondents who experienced a threat regarding their personal safety during the last year display a 20 times higher emigration intention compared to those who did not.

If we slightly relax the significance level and accept $p$-values higher than the standard 5\%, two other variables are validated: employability and corruption. Believing that it would be easy to find a similar or better job if the current one is lost hinders the international emigration likelihood, as persons who are confident in future job opportunities in their own country are naturally less prone to seek them 
abroad. The respondents who perceive themselves desirable in terms of employment and expect to easily find another job, are 0.803 times less likely to emigrate compared to those who consider finding a new job difficult. As for other variables (e.g. well-being or Romania's direction), potential emigrants hope to compensate for personal or social drawbacks by emigrating.

The perception of Romania being a corrupt country (based on previous experience of bribing) also enhances the emigration propensity. The Corruption Perceptions Index ranks Romania among the top corrupt EU countries (Transparency International 2016) and Romanians are fed up with the many inconveniences caused by corrupt practices in the public sector. The persons from our database who had to offer a bribe to public servants are 118 times more likely to emigrate. This result is also supported by recent research, which points to corruption as an emigration promoter, especially for the well-educated workforce (Cooray - Schneider 2014).

Moving forward, we now head to the highlight of our analysis: the identification of variables that influence the emigration propensity of our respondents in relation to their declared ethnicity, which will ultimately allow us to understand if such a decision varies or not based on cultural differences.

First, we concentrate on the results from the second binary logistic model, focused on teachers of Romanian ethnicity only, which indicated seven significant factors (at the 5\% significance level) that influence the intention to emigrate (Table 3), as well as another less significant factor (quality of public transport is significant at the $10 \%$ level).

The propensity to emigrate slightly decreases in relation to age, being $3.5 \%$ lower with each additional year of age. Likewise, when family is valued as very important, there is a $76.3 \%$ less risk of emigration compared to the reference group that declared family unimportant. The coefficient for the category that considers family important is statistically insignificant.

Three strong factors increase the intention to emigrate for the pre-university teachers of Romanian ethnicity: insufficient income, fear of threats, and dissatisfaction with the low quality of the environment (garbage on the streets). They enhance the probability to emigrate by $2.035,2.604$, and 2.615 times, respectively, in comparison with the reference group.

In contrast with the results from the whole dataset that did not validate any income variable, low earnings (as indicated by the variable "difficulty to pay the bills during the last 12 months") are a strong emigration promoter for the teachers of Romanian ethnicity. This is in accordance with other studies conducted on Romanian high-skilled professionals that pointed out income differentials between the home and the emigration country as an emigration trigger (Goschin - Roman 2014). 
Table 3. Results for the logistic regression on the emigration decision of pre-university teachers of self-declared Romanian ethnicity

\begin{tabular}{|c|c|c|c|c|}
\hline Variable & B & S. E. & Sig. & $\operatorname{Exp}(B)$ \\
\hline Age & -0.036 & 0.017 & .034 & .965 \\
\hline \multicolumn{5}{|c|}{ Family importance (reference group: unimportant) } \\
\hline Important & -19.904 & 40192.9 & 1.000 & .000 \\
\hline Very important & -1.440 & .615 & .019 & .237 \\
\hline Insufficient income (pay_bill) & 0.711 & 0.344 & 0.039 & 2.035 \\
\hline Threats & 0.957 & 0.383 & 0.012 & 2.604 \\
\hline $\begin{array}{l}\text { Environment quality (garba- } \\
\text { ge) }\end{array}$ & 0.961 & 0.339 & 0.005 & 2.615 \\
\hline Public transport quality & -0.631 & 0.360 & 0.080 & 0.532 \\
\hline Optimist about the future & -0.833 & 0.363 & 0.022 & 0.435 \\
\hline \multicolumn{5}{|c|}{ Health system evaluation (reference group: inadequate) } \\
\hline Good & 1.129 & 0.628 & 0.072 & 3.092 \\
\hline Very good & 1.510 & 0.556 & 0.007 & 4.528 \\
\hline \multicolumn{5}{|l|}{ Constant } \\
\hline $\begin{array}{l}\text { Hosmer and Lemeshow Test } \\
\text { (sign.) }\end{array}$ & \multicolumn{4}{|c|}{$7.564(0.477)$} \\
\hline No. of observations & \multicolumn{4}{|c|}{205} \\
\hline Nagelkerke R Square & \multicolumn{4}{|c|}{0.321} \\
\hline Cox-Snell R Square & \multicolumn{4}{|c|}{0.239} \\
\hline
\end{tabular}

Respondents who are optimistic about their future display an emigration intention 0.435 times lower than the pessimists. The optimists are justifiably less inclined to change their life since they hope it will improve in the future, while the pessimists are provoked to escape their negative expectations through emigration. This is in accordance with the results from the first model.

Respondents who are satisfied with the quality of public transport have a 0.532 times lower propensity to emigrate. The quality of the public transport variable is relevant because it can be considered a proxy for wider community services, the result being in accordance with expectations.

A finding that is more difficult to explain is that good and very good evaluations of the national healthcare system are positively associated with predilection towards emigration. This is surprising because the Romanian healthcare system is widely considered as being inefficient, underfinanced, poorly managed, and lacking both medical staff and materials (Haivas 2010). One possible explanation is offered by the age of the potential emigrants. Since the respondents who indicated emigration intention tend to be young, it is likely that they have little or no first-hand experiences with the shortcomings and deficiencies of the national healthcare system, therefore their answers to this item could be biased. 
We conclude our study by presenting the results from the third binary logistic model, which addressed the emigration propensity of the pre-university teachers of Romanian nationality who declared themselves to be of Hungarian ethnicity (Table 4). Six variables are significant at the 5\% level, while the variable "quality of public transport" is slightly less significant and has an unexpected positive sign, suggesting that persons satisfied with the public transport are more likely to emigrate. This is quite surprising and in contradiction with the findings for the teachers of Romanian ethnicity, whose likelihood to emigrate is negatively associated with the quality of public transport. Perhaps this variable should be discarded from the model.

Table 4. Results for the logistic regression on the emigration decision of pre-university teachers of self-declared Hungarian ethnicity

\begin{tabular}{l|c|c|c|c}
\hline Variable & B & S. E. & Sig. & Exp(B) \\
\hline Age & -0.036 & 0.017 & .034 & .965 \\
\hline Aims to improve education & 3.818 & 1.200 & .001 & 45.503 \\
\hline $\begin{array}{l}\text { Keeping in touch with } \\
\text { family }\end{array}$ & -2.176 & .778 & .005 & .113 \\
\hline There is corruption & 3.121 & 1.217 & .010 & 22.663 \\
\hline $\begin{array}{l}\text { Romania is going in the } \\
\text { right direction }\end{array}$ & -1.742 & .582 & .003 & .175 \\
\hline Respondent is happy & .735 & .354 & .038 & 2.086 \\
\hline Public transport quality & 1.511 & .828 & .068 & 4.531 \\
\hline Constant & 6.799 & 4.284 & .113 & 897.223 \\
\hline Hosmer and Lemeshow Test & \multicolumn{5}{|c}{0.114} \\
\hline No. of observations & \multicolumn{5}{|c}{0.608} \\
\hline Nagelkerke R Square & \multicolumn{5}{|c}{0.361} \\
\hline Cox-Snell R Square & \multicolumn{5}{|c}{} \\
\hline
\end{tabular}

Some results are similar to those obtained for the teachers of Romanian ethnicity. For instance, the propensity to emigrate slightly decreases by $3.5 \%$ with each additional year of age, exactly as in the second model.

In the case of the pre-university teachers of Hungarian ethnicity from Romania, a new variable enters the model. Keeping in touch with family members lessens the likelihood to emigrate by $89 \%$. This variable could be considered similar to "family importance" in the previous two models, as it indicates the strength of family ties and its direction of influence is as expected.

An unexpected result is related to the state of happiness felt by the respondents of this group: if happy, they are twice more likely to emigrate. If the level of happiness is analysed in relation to optimism (significantly higher for teachers of Hungarian ethnicity in our database, compared to ones of Romanian ethnicity), it 
suggests positive expectations and confidence in good things that life could offer abroad, and therefore a higher propensity towards risk-taking.

The strongest regressor in the third model is education improvement. The respondents of self-declared Hungarian ethnicity who plan to upgrade their knowledge and skills by attending various courses and gaining additional diplomas are 4.5 times more likely to emigrate. Intention to attend such courses by the potential emigrants suggests that they are actively preparing for emigration, trying to enhance the chances for rapid employment abroad through better qualifications.

Another important emigration trigger for teachers of Hungarian ethnicity is the perception that Romania is a corrupt country. They seem to react strongly to corruption, as the respondents who had to offer a bribe to public servants were 22.663 times more likely to emigrate, while this variable was insignificant in the model for the teachers of Romanian ethnicity.

These findings could explain the integrational profile of the persons of Hungarian ethnicity, who despite being economically assimilated (Constant - Zimmermann 2009), feel very strongly about their ties, keeping and passing along socio-cultural traditions of the ethnicity to which they feel they belong.

In sum, Romanian and Hungarian pre-university teachers are motivated by few similar and more dissimilar factors when thinking about emigrating from Romania, but one has to take into account that teachers of Hungarian ethnicity are considerably less prone to emigrate.

\section{CONCLUSION}

Aiming to reach a deeper understanding of the factors that determine the emigration propensity of pre-university teachers of Romanian nationality and to assess whether it varies in relation to their declared ethnicity, we applied logistic regression models and found different patterns in the migration decision-making process for teachers of Romanian and Hungarian ethnicity.

Teachers of Romanian ethnicity have a higher proclivity towards emigration, while those of Hungarian ethnicity display $50.6 \%$ less emigration propensity by comparison. Also, teachers of Romanian ethnicity work harder and earn more money, but they are less happy or optimistic about their future and encounter economic difficulties, sometimes being unable to pay their bills on time.

The common emigration determinants for the two ethnicity groups are age (emigration intention decreases along with aging) and family (the more important it is or the more support it offers, the less the propensity towards emigration), but these are general emigration determinants validated in most emigration studies, regardless of the geographical location or nationality of the surveyed groups. The 
real difference based on ethnicity is revealed when analysing the remaining identified determinants, which outline two distinct profiles: a more pessimistic and economic-driven behaviour in the case of the teachers of Romanian ethnicity and a more spiritual behaviour, with an emphasis on personal development, in case of the ones of Hungarian ethnicity.

The most important factors that trigger an emigration intention for the preuniversity teachers of Romanian ethnicity are related to financial reasons, safety, and the environment. Thus, those who encountered difficulties in paying their bills in the last 12 months, experienced threats to their personal safety, and were bothered by the garbage or disorder on the streets of their neighbourhood (looked upon as an escape from the effects of the broken windows theory or the ecological systems theory) are the most prone to emigrate.

For the pre-university teachers of Hungarian ethnicity, the most important emigration determinants are tied to personal education or corruption. Thus, those who declared that they would like to improve their education by taking courses for obtaining a second bachelor degree, a master, a $\mathrm{PhD}$, or other, and those who had to offer a bribe in order to benefit from a service which they are entitled to receive are the most inclined to emigrate.

It seems to us that the practical aspects of our current research are the following: raising awareness of the fact that Romanian teachers' emigration is on the verge of becoming a mainstream problem; offering the situation from the Commonwealth as an example to promote actions to be taken in advance; the identification of emigration triggers for Romanian teachers in general and for two distinct ethnicity groups in particular should indicate to policymakers the fields that require immediate intervention in order to prevent the situation from escalating.

As a closing line, we would like to point out the difference between emigration intention and actual emigration, as this distinction could represent an important avenue for follow-up research.

\section{REFERENCES}

Abramova, I. (2015): Grappling with Language Barriers: Implications for the Professional Development of Immigrant Teachers. Multicultural Perspectives, 15(3): 152-157.

American Federation of Teachers (2009): Importing Educators. Causes and Consequences of International Teacher Recruitment. Washington, D.C.

Anghel, R. (2012): The Migration of Romanian Croats: Between Ethnic and Labour Migration. Studia Sociologia, 57(2): 9-26.

Appleton, S. - Morgan, W. - Shives, A. (2006): Should Teachers Stay at Home? The Impact of International Teacher Mobility. Journal of International Development, 18(6): 771-786.

Aryal, T. (2005): Determinants of Rural Out-Migration at Household Level: Logistic Regression Analysis. Economic Journal of Nepal, 28(3): 169-177. 
Bense, K. (2015): International Teacher Mobility and Migration: A Review and Synthesis of the Current Empirical Research and Literature. Educational Research Review, 17(1): 37-49.

Bhopal, R. (2014): Migration, Ethnicity, Race, and Health in Multicultural Societies. Oxford: Oxford University Press.

Brubaker, R. (1998). Migrations of Ethnic Unmixing in the New Europe. The International Migration Review, 32(4): 1047-1065.

Cai, R. - Neli, E. - Michael, O. - Shuaizhang, F. (2014). International Migration Desires Related to Subjective Well-Being. IZA Journal of Migration, 3(1): 1-20.

Caravatti, M. L. - Lederer, S. - Lupico, A. - Van Meter, N. (2014). Getting Teacher Migration \& Mobility Right. Brussels: Education International.

Collins, J. - Reid, C. (2012). Immigrant Teachers in Australia. Cosmopolitan Civil Societies: An Interdisciplinary Journal, 4(2): 38-61.

Constant, A. - Zimmermann, K. (2009). Migration, Ethnicity and Economic Integration. IZA Discussion Paper, No. 4620.

Cooper, J. - Alvarado, A. (2006): Preparation, Recruitment, and Retention of Teachers. Paris / Brussels: International Academy of Education / The International Institute for Educational Planning.

Cooray, A. - Schneider, F. (2014): Does Corruption Promote Emigration? An Empirical Examination. Bonn: IZA Discussion Paper, No. 6894.

Cox, D. (1970): The Analysis of Binary Data. London: Chapman and Hall.

de Haan, A. - Yaqub, S. (2009): Migration and Poverty: Linkages, Knowledge Gaps and Policy Implications. Geneva: United Nations Research Institute for Social Development.

Education International (2016, 03 11): www.migrantteachersrights.org/get-engaged/best-practices. Retrieved from www.migrantteachersrights.org: http://www.migrantteachersrights.org/getengaged/best-practices/60-the-commonwealth-teacher-recruitment-protocol.

Eurofound (2016, 03 03): Retrieved from European Foundation for the Improvement of Living and Working Conditions: https://www.eurofound.europa.eu/eqls-2012-questionnaire-translation.

Finney, N. - Simpson, L. (2008): Internal Migration and Ethnic Groups: Evidence for Britain from the 2001 Census. Population Space and Place, 14(2): 63-83.

Fitzgerald, D. (2005): Nationality and Migration in Modern Mexico. Journal of Ethnic and Migration Studies, 21(1): 171-191.

Fox, J. (2007): From National Inclusion to Economic Exclusion Ethnic Hungarian Labour Migration to Hungary. Nations and Nationalism, 13(1): 77-96.

Global Migration Group (2014): Migration and Youth: Challenges and Opportunities. New York: United Nations Children's Fund.

Godri, I. (2004): A Special Case of International Migration: Ethnic Hungarians Migrating from Transylvania to Hungary. Yearbook of Population Research in Finland, 40(2004): 45-72.

Goschin, Z. - Roman, M. (2014): Romanian Migration and Remittances in an Economic Crisis Context. Bucharest: ASE Publishing House - Statistics and Econometrics Collection.

Hăisan, A. A. (2013): Disfunctionalitati in sistemul educational national (Malfunctions in the national education system). Cluj-Napoca: Presa Universitară Clujeană.

Haivas, I. (2010): Health Care in Romania: Fighting Collapse. Canadian Medical Association Journal, 182(7): 654-655.

Heid, B. - Larch, M. (2012): Migration, Trade and Unemployment. Open-Assessment E-Journal, 6(4): $1-42$.

Horváth, I. (2008): The Culture of Migration of Rural Romanian Youth. Journal of Ethnic and Migration Studies, 34(5): 771-786. 
Institute for Education Sciences - IES (2015): Analiza sistemului de învățământ preuniversitar din România din perspectiva unor indicatori statistici. Politici educaționale bazate pe dat (Romanian Pre-University Education System from the Perspective of Statistical Indicators: Evidence Based Policies). Bucuresti: Editura Universitara.

International Labour Organization (2002): Policy Responses to the International Mobility of Skilled Labour. Geneva.

Iredale, R. - Voigt-Graf, C. - Khoo, S. E. (2012): Trends in International and Internal Teacher Mobility in three Pacific Island Countries. International Migration, 53(1): 97-110.

Islam, R. - Nurullah, M. - Rahman, M. - Hossain, M. (2013): Actors Affecting on Migration to Chapai-Nawabganj City in Bangladesh: Multivariate Approach. American Journal of Economics, 3(6): 273-277.

Kocsis, K. (2007): Changing Ethnic Patterns in Transylvania since 1989. Hungarian Studies, 21(1-2): 181-203.

Koranyi, J. - Wittlinger, R. (2011): From Diaspora to Diaspora: The Case of Transylvanian Saxons in Romania and Germany. Nationalism and ethnic politics, 17(1): 96-115.

Leiden University (2016, 03 11): http://www.let.leidenuniv.nl. Retrieved from http://www.let. leidenuniv.nl/history/migration/index.html: http://www.let.leidenuniv.nl/history/migration/chapter131.html

Manik, S. (2014): South African Migrant Teachers' Decision-Making: Levels of Influence and 'Relative Deprivation'. Journal of Southern African Studies, 40(1): 151-165.

Mastekaasa, A. (2011): Brain Drain? Recruitment and Retention of High Quality Teachers in Norway. Oxford Review of Education, 37(1): 53-74.

Mojsoska-Blazevski, N. - Petreski, M. - Krliu-Handjiski, V. (2015): Does Cultural Heritage Affect Job Satisfaction: The Divide between EU and Eastern Economies. Acta Oeconomica, 65(2): 325-337.

Morgan, J. W. - Sives, A. - Appleton, S. (2006): Teacher Mobility, 'Brain Drain', Labour Markets and Educational Resources in the Commonwealth. Nottingham: Department for International Development, Researching the Issues, No. 66.

Nakahara, M. - Black, P. (2007): How I Survived as an Overseas Teacher of Japanese in Australia. Australian Review of Applied Linguistics, 30(1): 6.1-6.17.

Norredam, M. - Kastrup, M. - Helweg-Larsen, K. (2011): Register-Based Studies on Migration, Ethnicity, and Health. Scandinavian Journal of Public Health, 39(7-Suppl): 201-205.

OECD (2015): International Migration Outlook 2015.

OECD (2013): The OECD Teaching and Learning International Survey (TALIS).

OECD (2003): Trends in International Migration 2002 Continuous Reporting System on Migration: Continuous Reporting System on Migration.

Peri, G. (2013): The Economic Benefits of Immigration. Berkeley Review of Latin American Studies, Fall: 14-19.

Ramirez, A. - Rodriguez, Y. - Meteleski, D. (2015): Economic Factors Concerning the Migration of the Best Educated Workers. The Case of College Teachers. Comparative Economic Research, 18(4): 99-121.

Romanian Language Institute - RLI (2016, 06 25): http://www.ilr.ro/lccr/. Retrieved from http:// www.ilr.ro: http://www.ilr.ro/lccr/

Sharma, R. (2012): Teachers on the Move: International Migration of School Teachers from India. Journal of Studies in International Education, 17(3): 262-283.

South African Council for Educators (2011): Teacher Migration in South Africa. Advice to the Ministries of Basic and Higher Training. Centurion: South African Council for Educators. 
Timmerman, C. - Martiniello, M. - Rea, A. - Wets, J. (2015): New Dynamics in Female Migration and Integration. Oxon: Routledge .

Transparency International (2016, 03 07): https://www.transparency.org/country/\#ROU. Retrieved from https://www.transparency.org/country/: https://www.transparency.org/country/\#ROU

UNESCO (2016, 06 25): http://www.tellmaps.com/uis/teachers/. Retrieved from http://www.tellmaps.com: http://www.tellmaps.com/uis/teachers/

UNESCO Institute for Statistics (2014): Wanted: Trained Teachers to Ensure Every Child's Right to Primary Education. Montreal.

UNESCO (2011): Next Steps in Managing Teacher Migration. Paris.

Vojtovich, S. (2013): The Impact of Emigration on Unemployment in Slovakia. Inzinerine Ekonomika-Engineering Economics, 24(3): 207-216. 